\title{
The Bantu Presbyterian Church of South Africa and Ecumenism: 1923- 1939
}

\author{
Graham A Duncan \\ http://orcid.org/0000-0002-2583-1914 \\ University of Pretoria \\ graham.duncan@up.ac.za
}

\section{Farai Mutmiri}

University of Pretoria

\begin{abstract}
The Bantu Presbyterian Church of South Africa (BPCSA) was birthed out of a quest for union amongst Presbyterians, which began in the 1890s more than 30 years before it was actually established as the fruit of the mission of the United Free Church of Scotland in 1923. From that date onwards church union hardly ever disappeared from the agenda of the highest court of the denomination, the General Assembly. During the twentieth century such discussions involved two of the three other Presbyterian churches and the Congregational Union of South Africa. In addition, the BPCSA has maintained a high ecumenical profile in both the South African and global contexts. The main thrust of this article describes and analyses the vicissitudes of Presbyterian conversations during the period 1923-39.
\end{abstract}

Keywords: Bantu (Reformed) Presbyterian Church of South Africa (BPCSA, RPCSA); Tsonga (Evangelical) Church of South Africa (TPCSA, EPCSA); Presbyterian Church of South(ern) Africa (PCSA); United Congregational Church of South Africa (UCCSA) 


\section{Introduction and Background}

The Lord, indeed, as he has done from the beginning of the world, can wonderfully, in ways unknown to us, preserve the unity of the true faith, and prevent its destruction from the dissensions of men ... I should with pleasure cross ten seas, if necessary, to accomplish that object. (Calvin, Letter XVII to Cranmer, Archbishop of Canterbury, 1552)

This well-known quotation summarises the reforming view of ecumenism since the sixteenth century Reformation. It reminds us that the sixteenth century Reformations were an attempt, following many earlier attempts, to reform a corrupt church. There was no desire to establish new churches but to follow in the Lord's intention from creation.

However, in the course of time, the Reforming tradition developed a "defective genetic tendency towards schism" (a term coined by the late Presbyterian Prof Calvin Cook, Rhodes University, Grahamstown; cf Burleigh 1960, 457; Muirhead 2015, 1-3).

Following the Scottish Reformation it was many years before mission became a viable prospect. I have analysed this process elsewhere (Duncan 2013a, 205-220). Suffice to say that the beginnings of mission to South Africa were delayed until 1824. Prior to this, mission was dependent on forces outside the formal structures of the church; hence the growth and development of interdenominational voluntary societies. From 1924, the Free Church of Scotland (FCoS) engaged in South African mission.

At the Disruption (1843), the Free Church of Scotland came into being as the result of secession from the Church of Scotland. This had a significant impact on the Scottish mission in South Africa. The Glasgow Missionary Society had been active in South Africa since 1821 and from 1834 "the disputes of Scotland made themselves felt though restrained by the allegiance to a greater cause" (Drummond and Bulloch 1975, 166). In 1838 the Church of Scotland took responsibility for mission and subsequently "the Glasgow Missionary Society (GMS) adhering to the Principles of the Church of Scotland" attracted five missionaries while the newly formed Glasgow South African Missionary Society attracted two (Drummond and Bulloch 1975, 166). Until 1842 the two missions operated as one presbytery. In 1845, following the Disruption and the closure of the GMS, three mission stations, Lovedale, Burnshill and Pirie, were transferred 
by the Church of Scotland to the Free Church of Scotland while two, Chumie and Qhibira, were in 1847 transferred to the United Presbyterian Church of Scotland, the "Voluntaries", which was the progeny of the union of the Secession and Relief Churches (Hewat 1960, 180). The Free Church of Scotland and the United Presbyterian Church of Scotland united in 1900 to form the United Free Church of Scotland and in 1929 it, in turn, reunited with the Church of Scotland.

\section{Presbyterian Union in South Africa}

A first attempt at union took place in 1880 when a report on the relationship between the Free Church and United Presbyterian Presbyteries of Kaffraria was prepared (Report of Committee on Union between the Free Church and United Presbyterian Presbyteries of Kaffraria, 1884, William Cullen Library [WCL], University of the Witwatersrand [Wits], Ac1971/Ag2). Nothing came of this attempt until in 1891 a Federal Council was established to promote union. At its fourth meeting in 1895, a draft constitution was presented having been scrutinised by sessions, congregations and presbyteries. It was then sent to participating "Churches and Presbyteries." The Colonial Committee of the FCoS expressed its support, particularly in terms of "the Christianisation of the native races, and the consolidation of the Christian communities in South Africa" (PCSA, Rae to Federal Council, Minutes 16 July 1895, 19 March 1895). At this stage the UPCoS missions decided to participate in the union although the UFCoS missions subsequently voted to remain separate as the Synod of Kaffraria. It clearly "feared that the predominantly white PCSA would allow racial discrimination to determine its life and work, including its mission policy" (Hunter 1983, 1). Further, the failure of the PCSA to clarify the grounds on which black congregations could achieve full status led the Synod of Kaffraria to conclude that the PCSA policy would be determined by "the principle of white trusteeship expressed in the political sphere. Both churchmen and politicians had to face up to the crucial question: What happens when the ward grows up? What determines his majority?" (Hunter 1983, 24). The issue of status would be aggravated when the care of black PCSA congregations was placed under supervision of its Mission Committee.

The union was consummated on 27 September 1897. The Presbyterian Church of South Africa (often referred to as the South African Presbyterian Church, e.g. Lennox 1911, 81, and what was "termed the colonial Presbyterian Church" [Shepherd 1971, 88]) had four presbyteries along with the congregation of Port Elizabeth. It was clear from the beginning that issues of 
race and distrust were evident, as can be seen from those who did not participate in the union. Yet, they were seen quite differently by white proponents of the venture. The General Assembly was not convinced of these arguments, which were:

... not deemed sufficient to prevent the consummation of the union ... 1) that the application of Presbyterian principles will obviate difficulties as to the balance between Colonial and Mission churches; and 2) that the matter of a final court of appeal has been adequately dealt with ... in the draft constitution, and which has now been adopted by the General Assembly as part of the constitution of the Presbyterian Church of South Africa. (Proceedings of the First General Assembly, PCSA [1897], WCL, Ac1971/Ah1.1:26-27)

From its inception, the PCSA's mission work among the indigenous peoples became the responsibility of the Mission Committee, while mission work among whites was the preserve of the Colonial Committee-soon to become the Church Extension Committee. As a result, those whose fears regarding union on the grounds of race were justified (Cory Library for Historical Research, MS Ac1971/Ag 2:8).

Richard Elphick (2012, 7-8) makes the central claim:

... that the struggle over racial equalisation ... was pivotal to South African history; that this concept was rooted in the missionaries' proclamation of God's love to all people, as manifested in the birth, crucifixion and resurrection of Jesus; that the ideal of equality was nurtured in large part by missionary institutions, even though missionaries themselves repeatedly sought to limit, deflect or retard its achievements ... There is, therefore, a history of an idea in relationship with institutions and the people who ran them.

While it is clear that both branches of Presbyterianism viewed black people as objects of mission, the Scottish mission, through a combination of evangelism and education sought to raise black people to take care of their own affairs. It was a basic missionary principle that:

... missions should found local churches under local leadership. Whatever their personal reservations about Africans' abilities, no missionaries publicly advocated 
perpetual European domination of the African church. In theory, the principles of Christian universalism and the indigenous church dovetailed neatly, since the proclamation of a single gospel throughout the world would give rise to churches equal in stature though implanted in different cultures. In South Africa, however, where white Christians had founded well-endowed and cohesive churches, the two principles were in tension. Universalism in South Africa meant close fellowship and effective equality between white and black Christians, while the doctrine of indigenous churches implied that Africans, with their distinctive cultures, would go their own way, as whites would go theirs. (Elphick 2012, 94-95).

This concept made union problematic as both Presbyterian bodies were operating from different discourses, the one colonial and the other mission oriented. Elphick asserts that ecumenism was bound up with the transfer of property and power from missions to the "native" churches they had founded, but in South Africa, as Thomas has demonstrated, ecumenism retarded indigenisation and prolonged missionary power.

On a typical mission field, the distinction between mission and church was fairly clear. Under the three-self policy enunciated by English and American evangelical mission societies in the nineteenth century, missions would found "native churches" in regions far from their homeland and gradually transfer their authority and assets to them. Two such "native churches" had been founded by English-speaking missions in South Africa: one Presbyterian [BPCSA], one Congregational ... in South Africa the model of "indigenisation" was vastly complicated by the fact that most truly black churches, the so-called African Independent Churches, had not been founded by white missionaries at all, and hence had no need to assert their independence; viewed warily by missionaries and white churchmen, these churches played no role in ecumenical affairs until the 1960s. (Elphick 2012, 269)

These African initiated Churches (AICs) added another dynamic to the tapestry of southern African Christianity, even within the Presbyterian corpus due to the Mzimba secession of 1898 (Duncan 2013b). 


\section{BPCSA - Ecumenism}

The story of the internal ecumenical struggle between the PCSA and the Scottish mission from 1897 until 1923, when the BPCSA was formed as a separate Presbyterian denomination, has been recounted in Duncan (2016): "The formation of the Bantu Presbyterian Church of South Africa." The substantial reason for the emergence of two denominations rather than one was racism but the semi-official reason was that union with the Presbyterian Church of South Africa was not in the best interests of the black people in the Scottish mission (SAO, November 1973, 2); the PCSA's desire to form a federal arrangement was rejected since such "a relationship with the PCSA would in future discredit the witness of both churches" (Imvo Zabantsundu 7 August 1923). In the first General Assembly of the BPCSA it was decided to "have a special relationship with the Presbyterian Church of South Africa, in that each should be represented in the highest court of the other by six Associate Members" (BPCSA 1923, 20). This "special relationship" was to be exposed to many strains and stresses in succeeding years. However, the PCSA's desire for union remained.

An early example is to be found within the jurisdiction of the Presbytery of Mankazana (Baviaans River: Soga 1862, 167). This was the presbyterial area where the two missions of the United Presbyterian Church (which aligned itself with the United Free Church of Scotland) and the Free Church of Scotland (which aligned itself with the Bantu Presbyterian Church) were active and where the stresses of Presbyterian ecumenism were most deeply expressed. In the 1925 General Assembly, note a decision of the PCSA General Assembly (PCSA 1924 Min 106):

The Assembly heard with grateful appreciation the resolution of the Bantu Assembly regarding the ministers of the Presbytery of Mankazana, and requests such Ministers, who are Ministers of this Church, to intimate their acceptance of the position indicated, namely, that of Assessors, with full rights, in the Assembly of the Bantu Church and in the Mankazana Presbytery. (BPCSA 1925-26, 34)

The same agreement was made regarding missionaries serving white congregations. "It was noted that the work referred to ... does not come under the Bantu Presbyterian Church" (BPCSA 1925-26, 34). These were two separate projects under two separate denominations, although there was to be a degree of mutual recognition of ministries. 
At least there was some progress made in the decision of the PCSA to avail themselves of the training facilities for the ministry at the University of Fort Hare:

Uniformity of training for native students as between ourselves and the Bantu Presbyterian Church being desirable, the Assembly recommends amalgamation of schemes and the use of facilities provided at Fort Hare. (PCSA 1925, 21)

Further, it is interesting to note that the PCSA appointed a Free Church of Scotland missionary from the BPCSA as a superintendent of its native missions in the Transvaal, in the person of Rev. Dugald WM Matheson (PCSA 1925, 40). However, the general tenor of PCSA members at this time was not focused on integration but on separation. The Committee on Life and work concluded:

There seems to be a general opinion throughout the church that the European and coloured races should worship separately. There is a strong conviction that this is as much a desire of the coloured people as of the Europeans. Mutual help and sympathy can exist in all matters of Christian service without tempering with social barriers which the peculiar conditions of South Africa render necessary. (PCSA 1925, 126)

This was confirmed by the 1927 General Assembly of the PCSA-when they had an opportunity to consolidate their desire for union - and rather than integrate the small population of white members of the PCSA in the Transkei with the BPCSA, which was particularly strong there, they resolved "to appeal to the Students of that Church [the UFCoS] to make the provision of the means of grace in the Transkei the object of their mission plea during the next session" (PCSA 1927, 26).

An unfortunate situation occurred in 1927 when Rev. W. P. T. Ndibongo was regularly appointed as missionary to the BPCSA Glenthorn congregation and was denied the right to reside on the property. The Glenthorn congregation of the Presbytery of Port Elizabeth refused to consider an application to occupy land for this congregation. This led to the appointment of a joint commission to consider the matter (BPCSA 1928, 23). The commission found that the PCSA minister at Glenthorn had not been appointed to the native congregation. The commission found also that the property was vested in the PCSA as a gift from the FCoS and that in doing so, they "have an interest in the gift" (BPCSA 1928, 27). Appeals were made to 
both parties to accept the de facto situation and to exercise discretion in carrying out their respective duties. By 1930 there was no clear solution in view, although several alternative possibilities were explored (BPCSA 1930-1931, 35-360; BPCSA 1931-1932, 45). Interestingly, no mention is made of this incident in either of the histories of the Glenthorn congregation (De Villiers 2011; Glenthorn Presbyterian Church 1990).

This was followed by a confusing minute of the Assembly (Minute 584, BPCSA 1928, 46): "Rev. T. B. Soga submitted correspondence regarding possible union with the Presbyterian Church of South Africa (Mzimba)." What is confusing is that the PCSA and the Mzimba Church (The Presbyterian Church of Africa [PCA] or the African Presbyterian Church were two separate churches. The PCA was a church which split from the Scottish mission in 1898 and it is difficult to see how these were confused; it is also difficult to see how the BPCSA could contemplate union with the PCA at that time. However, the name of Mzimba is problematic in this context. Again, a committee was formed to consider the matter and report in 1929. No report is recorded.

At this time the issue of BPCSA church members working in urban areas, particularly Cape Town, became manifest in their "craving for their church" (BPCSA 1934, 29; cf PCSA 1932, 34) for the BPCSA until this time had exercised its mission almost exclusively in rural areas. There was a problem in Uitenhage "through the work of the Rev. GG Miza of the Bantu Presbyterian Church in the Port Elizabeth District" (PCSA 1932, 135). This was further exacerbated by receipt of "a petition from four persons in the congregation of New Brighton, two Elders and two Deacons, in the name of two hundred members, candidates and children, who ask to be received into the Bantu Presbyterian church" (PCSA 1932, 136). This became the subject of a commission.

The view of the PCSA was set out in a decision made at its General Assembly on 18 September 1934 along with the desire that "some day we hope to be one Church."

When the General Assembly released the ministers and congregation of the Kaffraria and Mankazana presbyteries our understanding was that the Native mission work of our Assembly should be carried on and should have its natural development in the districts in which it was already established, the Bantu Church taking over the mission work in the areas where it had congregations. 
By this arrangement the Presbyterian Church of South Africa would be responsible for mission work in Cape Town and the western area of Cape Province, in Port Elizabeth District, in Durban, in the area embraced by the Orange River Native Presbytery, on the Witwatersrand and in Pretoria. Work in the Northern Transvaal was to be continued by both Churches, each in its own sphere, and development there was to proceed according to opportunity and success, each Church being careful not to intrude upon the area occupied by the other or to interfere with the natural growth of each other's work. (BPCSA 1934, 47-48)

There appears to be no evidence that the BPCSA ever accepted this "understanding"/ arrangement although they were aware of it (Minute 1080, BPCSA 1934, 28) although Xapile $(1999,82)$ claims that they did, but without citing a reference (cf. Xapile 1994, 29). It is difficult to contemplate how this could be considered an equitable arrangement while the membership of the BPCSA was mobile in terms of work migration and the PCSA had congregations both in urban and rural areas. For them it was a win-win situation, though the BPCSA lost valuable income while their members spent their working lives in PCSA congregations and returned to their own BPCSA congregations when they ceased to be wage earners. This was to become a constant thorn in the flesh of attempts at union until the negotiations which brought the UPCSA into being from 1994-1999 (see e.g. PCSA 1937, 134-135).

The Presbytery of the Ciskei petitioned the BPCSA Assembly regarding their place of membership. In an attempt to reconcile the situation, Rev. W. P. T. Ndibongo (BPCSA 1934, 29) gave notice of motion:

I beg to move that the Bantu Presbyterian Assembly should respectfully ask the Presbyterian Church Assembly to meet each other half way, by peacefully handing over all their Native congregations to the Bantu Presbyterian Church, and that the minister or Ministers of the Presbyterian Church in charge of the Native Congregations be a member or members in the Bantu Presbyterian Assembly as it was in the then Mankazana Presbytery. (BPCSA 1934, 29)

This was a conciliatory move to restore the anticipated harmony between the two Presbyterian denominations. It was followed by a proposal that in the absence of clear boundaries between 
the congregations of the two denominations, a joint council be established in order to "discuss distribution of forces for the highest interests of the Kingdom of God" (BPCSA 1934, 37). This was agreed. However, Rev. S. W. Njikelana and 14 others entered their dissent with others claiming that this decision was flawed due to, inter alia:

There are no defined boundaries between the Bantu Presbyterian Church and the Presbyterian Church of South Africa, insomuch as the Presbyterian Church of South Africa has invaded Bantu Church congregations in the Mankazana Presbytery or Presbytery of Adelaide.

As the people of Cape Town had left the Presbyterian Church of South Africa in a regular manner, having been furnished with disjunction certificates by the Kirk Session of Cape Town, it is irregular to decline serving ordinances to them for any period however short the time may be. (BPCSA 1934, 37)

It was recommended and agreed that a Joint Council be formed:

On which both churches shall be represented and which shall be charged with the duty of reviewing the whole field, and considering how the available forces of the two churches can best be distributed so as to make the most effective contribution to the work of the Kingdom of God. (BPCSA 1934, 54)

Despite this, a report was received in the 1935 General Assembly of the BPCSA from the Joint Council formed in 1928. It stated, inter alia:

That the speedy organic union, considerately proposed, affect for the future only the Bantu and the Presbyterian Churches of South Africa, Native Mission work and property and that alone.

That in the very critical and complex situation which has arisen, places like Cape Town, Johannesburg and the like be henceforth created into Preaching Stations with respective Sessions coming directly under this Bantu General Assembly, and that ultimately this Assembly resolve that these be sent down to the Appointments Committee for settlement. (BPCSA 1935, 35-36) 
The view was taken that the only solution to the constant internecine conflict was organic union (Xapile 1999, 85). An unfortunate situation arose from a proposal, by Dr Arthur Wilkie of the BPCSA rejecting union, resulting from this report relating to proceeding to union and resignations from all committees ensued (BPCSA 1935, 36-39). The General Assembly of the PCSA continued with its view on the value of union with the BPCSA (BPCSA 1935, 40-41) but an impasse had arisen. "The occasion had underlined the fact that there was resistance within the Church to any union with the PCSA" (Xapile 1999, 86).

In a sterling effort to resolve this crisis, Rev. Holfort Mama produced a principle for consideration which was agreed. This would attempt to safeguard the close co-operation for which "each has at heart":

... where the Presbyterian Church of South Africa is firmly established, and into which the Bantu Presbyterian Church has recently entered, Mr Mama advocated that the agents of the latter Church be withdrawn, and that members of that Church, coming into these areas, be received as members of the Presbyterian Church [of South Africa], and be ministered to by the Minister of that Church ... Put briefly, his policy is, that where the one Church is in numbers and organisation clearly more fitted for undertaking the work, the Other Church should withdraw and the arrangement outlined be given a chance to work. (BPCSA 1938, 18)

Such members would simply be under the care of the other church for the duration of their stay in the urban area (and be placed on a separate roll), and would be expected to contribute towards the minister's stipend. This arrangement would apply specifically to the Cape, the Reef and Port Elizabeth (including Tarkastad and Glenthorn). The Joint Council committee subsequently framed a policy agreement in the following words:

A co-operation that would admit of members of the one Church, while maintaining their identity with that Church, being received as members of the other and a co-operation that would ensure due recognition of the rights of the Church so loaning and gifting its members the sister Church to an equitable distribution of that support every church has the right to expect of its members. (BPCSA 1938, 19) 
This seemingly innocuous arrangement, however, had a seriously negative side. First, it has to be recognised why these members were moving from rural to urban areas. As a result of the rise of industrialisation and urbanisation (the "pull" factor) the rural areas were becoming increasingly impoverished and people had to move to the towns to secure work areas (the "push" factor). This migratory mobility had serious detrimental effects on rural congregations (mainly of the BPCSA). The issue of ministers' stipends in urban areas was an issue, but a more serious issue was who was going to pay for ministers' stipends in rural areas? Hence, the issue was an economic one. Members would normally return to their rural homes on retirement on when unable to work, e.g. through injury or retirement, and would still be unable to support the life, work and witness of their rural congregations. The PCSA clearly benefitted from this arrangement over many years. The overriding concern expressed was "the maintenance of harmony between the two Churches" (BPCSA 1938, 19).

The BPCSA $(1938,18-19)$ responded with a list of comments relating to the policy advocated by the Joint Council:

1) It be understood that where one of these sister churches first occupied a field as in these specially affected localities the Ministers of that Church be allowed to take charge of that work for the Church which entered the field later, i.e. that the Bantu Presbyterian Church congregations in Cape Town, Tarkastad and Glenthorn be under the supervision of the Presbyterian Church of South Africa Ministers who may be already labouring in the said localities, and on the distinct understanding that they will have a separate and a distinct organisation from that of the PC of SA Congregation, and shall be known as Bantu Church Congregations.

2) That these Bantu Church congregations worked by the PC of SA Ministers will have the same status as all Bantu Church Congregations and be responsible to the Bantu Church Assembly and abide by its constitution.

3) That contributions received from such Bantu Church Congregations be remitted to the Bantu Church Assembly for their disposal and having due regard to the necessity of meeting expenses of the Presbyterian Church of SA Minister.

4) That in large centres of labour such as Johannesburg, which permit many churches, this procedure shall not apply.

5) The Congregations already formed by the Bantu Presbyterian Church be allowed to continue under the direct ministration of the Bantu Presbyterian Church Ministers and 
in that case it would be advisable for the Presbyterian Church Assembly to hand over the empty buildings in those areas for the use of the Bantu Congregations, and the Presbyterian Church continue to do its work on the Rand as before.

6) The suggestion about the work in Johannesburg is made in view of the fact that we have already an old and a large Mission Field in Northern Transvaal which may easily be coupled with our work already begun in Johannesburg.

7) We would further remark as the Rev. JY Hliso is working in the Bantu Presbyterian Church Congregation at Port Elizabeth, the work of the Presbyterian Church of SA there could be placed under his supervision with the same privileges as those applicable to the Presbyterian Church of SA Ministers in charge of work under the Bantu Presbyterian Church as in the case of Cape Town, etc.

In our view an agreement on these lines will result in the settlement of the present conflict in the field and provide the basis of harmony in the future. (BPCSA 1938, 2021)

The PCSA accepted this proposal, but a major BPCSA concern here was the fear that their congregations would lose their full status and be reduced to the status of missions (point 2 above) and lose much needed income for the support of their ministers (point 3 above). Point 4 was an attempt to begin with a level playing field for missionary outreach in a context where many denominations were operating. Point 5 followed from this and sought to preserve the integrity of work already established in urban areas. Point 6 referred to a specific case where PCSA work could be entrusted to the care of a BPCSA minister in an urban area. All of these issues emanated from a position of lack of trust and insecurity regarding the future development of the BPCSA. The fact that these issues were raised in the first place, indicates that the longterm view remained that of separate churches rather than one united denomination.

The Joint Council met at the University of Fort Hare on 3 May 1939 and it became clear that there was considerable disagreement regarding the best way in which the two denominations could both relate to one another while they tried to witness to the gospel (Xapile 1999, 90). Xapile $(1999,91)$ summarised the impasse correctly: "It is evident that the Bantu Presbyterian Church from now on did not take the union seriously." Two senior BPCSA ministers revealed this in different ways. Rev. W. P. T. Ndibongo maintained his 1934 position that the PCSA should transfer its African work to the BPCSA (Robertson 1994). This view was supported by 
the majority of BPCSA members (Xapile 1999, 96). Rev. D. V. Sikhutshwa (SAO December 1939) published an article in the South African Outlook (SAO) in which he stated that union was an "absolute impossibility."

Matters deteriorated when it was reported to the 1939 General Assembly of the BPCSA that the PCSA Presbytery of Port Elizabeth had placed a minister in New Brighton, which had been a vacant congregation when the Joint Council provisions had been agreed. It appears that this was a charge where the PCSA had been active earlier than the BPCSA PCSA (1939, 23): “... what this really implied was that very few congregations, if any, in the cities would be BPC as it was obvious that the PCSA had had an earlier presence" (Xaplie 1999, 92). The result was the reversion to the 1938 suggestions made by Rev. Holfort Mama. From this point little progress was made in the ecumenical front and negotiations ground to a virtual halt.

It was at this time (1937) that the Faith and Order Conference met in Edinburgh (Best 1992). It noted three models relating to church unity-co-operative unity, mutual recognition and organic union. In the South African context the first worked sporadically; the second was a reality and the third at this stage was seemingly unattainable. Yet, Xapile $(1999,99)$ was confident:

A union was possible. It was necessary in order that both blacks [sic] and white Christians stand united not only as regards ecclesial matters but also as a united front against apartheid. Some members of the BPC were not convinced that a united church would help them towards their goal. They wondered if it would not add to their suffering. Sadly, those who held this view won. The people of God, the church, had to wait for politics to dictate how they should do things.

\section{Conclusion}

While there was a persistent desire on the part of the PCSA for union with the Scottish mission from the beginning of its negotiations in 1891, and more so after its formation in 1897 , this was not reciprocated on the part of the mission or the BPCSA before and from the time when it was established in 1923. What became clear before and after 1923 was that there was a clear problem of distrust on the part of BPCSA ministers and members, linked to being oppressed by racist white Christians and a clear unwillingness to share power, property and other assets 
on the part of white PCSA leaders. These two concerns meant that progress was virtually impossible. This was the beginning of a century long (1891-1999) project that would later involve the PCSA, the BPCSA, the Congregationalists and the Swiss Mission (Tsonga, later Evangelical Presbyterian Church). It would be marked at times by enthusiasm, frustration, procrastination and thrawnness (Scottish: stubbornness, obstinacy) which would prevent union until 1999 when the PCSA and the BPCSA united to form the Uniting Presbyterian Church in Southern Africa

\section{References}

Bantu Presbyterian Church of South Africa. Archives. Cory Library for Historical Research, Rhodes University, Grahamstown.

Bantu Presbyterian Church of South Africa (BPCSA) 1923, 1925, 1928, 1930-1931, 19311932, 1934, 1935, 1938. Proceedings of the General Assembly. Lovedale: Lovedale Press.

Best, T. 1992. Living Today towards Visible Unity: Faith and Order paper no. 142. Geneva World Council of Churches.

Burleigh, J. H. S. 1960. A Church History of Scotland. Oxford: University Press.

Calvin, J. 1552. Letter XVII to Thomas Cranmer, Archbishop of Canterbury, 1552. http://reformationanglicanism.blogspot.co.za/2010/12/letter-xviicalvin-to-cranmerarchbishop.html (accessed 21 November 2016).

De Villiers, J. H. G. 2011. Presbyterians on the Koonap: 150th Anniversary of the Church, 1861-2-11. Adelaide: Moderator and Session.

Drummond, A. L., and Bulloch, J. 1975. The Church in Victorian Scotland, 1843-1874. Edinburgh: St Andrew Press.

Duncan, G. A. 2013a. "The Origins and Early Development of Scottish Presbyterian Mission in South Africa (1824-1865).” Studia Historiae Ecclesiasticae XXXIX (1, May): 205-220.

Duncan, G. A. 2013b. “African Churches Willing to Pay their Own Bills: The Role of Money in the Formation of Ethiopian Type Churches with Particular Reference to the Mzimba Secession." African Historical Review 45 (2): 52-79. https://doi.org/10.1080/17532523.2013.857092.

Duncan, G. A. 2016. "The Formation of the Bantu Presbyterian Church of South Africa." International Journal of African Historical Studies, 49 (3): 329-360.

Elphick, R. 2012. The Equality of Believers: Protestant Missionaries and the Racial Politics of South Africa. Charlottesville \& London: University of Virginia Press. 
Glenthorn Presbyterian Church 1990. Tercentenary: Celebrating 150 years at the Glenthorn Presbyterian Church. Adelaide: Moderator and Session.

Hewat, E. G. K. 1960. Vision and Achievement, 1796-1956: A History of the Foreign Missions of the Churches United in the Church of Scotland. London: Thomas Nelson $\&$ Sons

Hunter, C. F. D. 1983. "Some Aspects of the African Mission Policy of the Presbytery of Adelaide/ Port Elizabeth with Special Reference to the Origin and Development of the New Brighton Mission Church, 1898-1962." PhD thesis, Grahamstown: Rhodes University.

Imvo Zabantsundu [IZ] 1923. 7 August.

Lennox, J. 1911. Our Missions in South Africa: Missions of the United Free Church of Scotland. Edinburgh: Foreign Mission Committee, United Free Church of Scotland.

Muirhead, A. 2015. Reformation, Dissent and Diversity: The Story of Scotland's Churches, 1560-1960. London: Bloomsbury T \& T Clark.

Presbyterian Church of South Africa 1891- . Archives. William Cullen Library [WCL], University of the Witwatersrand [Wits], Johannesburg.

Presbyterian Church of South Africa (PCSA) 1924, 1934. Proceedings of General Assembly. Johannesburg: PCSA.

Robertson, R. 1994. “The Union that Fell Through.” Unpublished paper, Cape Town.

Shepherd, R. H. W. 1971. Lovedale, South Africa: 1824-1955. Lovedale: Lovedale Press.

Sikhutshwa, D. V. 1939. South Africa Outlook (SAO), December.

Soga, T. 1862. "Gxuluwe and the Bushmen." In The Journal and Selected Writings of the Reverend Tiyo Soga. Edited by Williams, D 1983. Cape Town: AA Balkema.

South African Outlook [SAO] 1973. November: 2.

Thomas, D. G. 1984. "Ecumenism and Indigenisation in the Churches of South Africa, 19041975.” Master's dissertation, Johannesburg, University of the Witwatersrand.

Xapile, S. P. 1994. Unity Negotiations between the Bantu Presbyterian Church and the Presbyterian Church of Southern Africa (1959-1971). Cape Town: University of Cape Town.

Xapile, S. P. 1999. The Quest for Unity between the Bantu Presbyterian Church of South Africa and the Presbyterian Church of South Africa, 1959-1973. Stellenbosch: University of Stellenbosch. 